\title{
Circulating Polyunsaturated Fatty Acids as Biomarkers for Dietary Intake across Subgroups: The CODAM and Hoorn Studies
}

Citation for published version (APA):

Wanders, A. J., Alssema, M., De Hoon, S. E. M., Feskens, E. J. M., van Woudenbergh, G. J., van der Kallen, C. J., Zock, P. L., Refsum, H., Drevon, C. A., Elshorbagy, A., Schalkwijk, C. G., Stehouwer, C. D. A., Dekker, J. M., \& van Greevenbroek, M. M. J. (2018). Circulating Polyunsaturated Fatty Acids as Biomarkers for Dietary Intake across Subgroups: The CODAM and Hoorn Studies. Annals of Nutrition and Metabolism, 72(2), 117-125. https://doi.org/10.1159/000486244

Document status and date:

Published: 01/01/2018

DOI:

10.1159/000486244

Document Version:

Publisher's PDF, also known as Version of record

Document license:

Taverne

Please check the document version of this publication:

- A submitted manuscript is the version of the article upon submission and before peer-review. There can be important differences between the submitted version and the official published version of record.

People interested in the research are advised to contact the author for the final version of the publication, or visit the DOI to the publisher's website.

- The final author version and the galley proof are versions of the publication after peer review.

- The final published version features the final layout of the paper including the volume, issue and page numbers.

Link to publication

\footnotetext{
General rights rights.

- You may freely distribute the URL identifying the publication in the public portal. please follow below link for the End User Agreement:

www.umlib.nl/taverne-license

Take down policy

If you believe that this document breaches copyright please contact us at:

repository@maastrichtuniversity.nl

providing details and we will investigate your claim.
}

Copyright and moral rights for the publications made accessible in the public portal are retained by the authors and/or other copyright owners and it is a condition of accessing publications that users recognise and abide by the legal requirements associated with these

- Users may download and print one copy of any publication from the public portal for the purpose of private study or research.

- You may not further distribute the material or use it for any profit-making activity or commercial gain

If the publication is distributed under the terms of Article $25 \mathrm{fa}$ of the Dutch Copyright Act, indicated by the "Taverne" license above, 


\title{
Circulating Polyunsaturated Fatty Acids as Biomarkers for Dietary Intake across Subgroups: The CODAM and Hoorn Studies
}

\author{
Anne J. Wanders ${ }^{a}$ Marjan Alssema ${ }^{a, b}$ Sabine E.M. De Hoon ${ }^{a, c}$
}

Edith J.M. Feskens ${ }^{c}$ Geertruida J. van Woudenbergh ${ }^{c}$ Carla J. van der Kallen ${ }^{d}$

Peter L. Zock ${ }^{a}$ Helga Refsum $^{\mathrm{e}}$ f Christian A. Drevon ${ }^{\mathrm{e}}$ Amany Elshorbagy ${ }^{\mathrm{f} g}$

Casper G. Schalkwijk ${ }^{d}$ Coen D.A. Stehouwer ${ }^{d} \quad J^{2}$ acqueline M. Dekker ${ }^{\text {b }}$

Marleen M.J. van Greevenbroek ${ }^{d}$

\begin{abstract}
a Unilever Research and Development, Vlaardingen, The Netherlands; ${ }^{b}$ Department of Epidemiology and Biostatistics and EMGO Institute for Health and Care Research, VU Medical Center, Amsterdam, The Netherlands; ${ }^{c}$ Division of Human Nutrition, Wageningen University, Wageningen, The Netherlands; ${ }^{d}$ Department of Internal Medicine, Maastricht University, Maastricht, The Netherlands; ${ }^{e}$ Department of Nutrition, Institute of Basic Medical Sciences, Faculty of Medicine, University of Oslo, Oslo, Norway; ${ }^{f}$ Department of Pharmacology, University of Oxford, Oxford, UK; ${ }^{9}$ Department of Physiology, Faculty of Medicine, Alexandria University, Alexandria, Egypt
\end{abstract}

\section{Keywords}

Dietary fat · Circulating fatty acids · Biomarker .

Polyunsaturated fat

\begin{abstract}
Aims: To evaluate whether participant characteristics and way of expressing circulating fatty acids (FA) influence the strengths of associations between self-reported intake and circulating levels of linoleic acid (LA), alpha-linolenic acid (ALA), eicosapentaenoic acid (EPA), and docosahexaenoic acid (DHA). Methods: Cross-sectional analyses were performed in pooled data from the CODAM $(n=469)$ and Hoorn ( $n=702)$ studies. Circulating FA were measured by gas liquid chromatography and expressed as proportions (\% of total FA) and concentrations $(\mu \mathrm{g} / \mathrm{mL})$. Dietary intakes were calcu-
\end{abstract}

\section{KARGER}

(c) 2018 S. Karger AG, Basel

E-Mail karger@karger.com

www.karger.com/anm lated from a validated food frequency questionnaire. Effects of participant characteristics on associations between dietary and circulating FA were calculated using interaction analyses. Results: Standardized regression coefficients between dietary FA and proportions of circulating FA (\% of total FA) were $L A \beta=0.28, A L A \beta=0.13, E P A \beta=0.34$, and $D H A$ $\beta=0.45$. Body mass index (BMI), waist circumference, and presence of CVD influenced associations for LA; gender influenced $L A, E P A$, and DHA; alcohol intake influenced $L A$ and DHA; and glucose tolerance status influenced ALA ( $p$ values interaction $<0.05$ ). Coefficients for circulating $F A$ as concentrations were $L A \beta=0.19, A L A \beta=0.10, E P A \beta=0.31$, and $D H A$ $\beta=0.41$. Conclusions: This study suggests that characteristics such as BMI, alcohol intake, and expressing circulating FA as proportions or concentrations, influence associations between dietary and circulating FA.

(c) 2018 S. Karger AG, Basel
Anne J. Wanders

Unilever Research and Development

Olivier van Noortlaan 120

NL-3133 AT Vlaardingen (The Netherlands)

E-Mail anne.wanders@unilever.com 


\section{Introduction}

Methods used to monitor dietary intake in population-based research often rely on self-reported dietary assessment. However, the subjective nature of self-reported dietary intake may lead to measurement error, which can result in obtaining inaccurate estimates of dietary intake and obscured associations with disease $[1,2]$.

For assessing total fat intake, no valid biomarker is available. Instead, proportions of circulating fatty acids (FA) are often used as biomarkers of intake of specific dietary FA $[3,4]$. In particular, FA that are not (or in small amounts) synthesized endogenously, such as linoleic acid (LA; C18:2 n-6), alpha-linoleic acid (ALA; C18:3 n-3), eicosapentaenoic acid (EPA; C20:5 n-3) and docosahexaenoic acid (DHA; C22:6 n-3) correlate reasonably well with their respective reported intakes [4]. However, the relationship between dietary and circulating FA also tends to vary. In their review, Hodson et al. [4] reported correlation coefficients ranging from 0.01 to 0.77 for LA and from 0.21 to 0.69 for EPA.

The variation in correlation coefficients between studies may be explained by measurement error, time frame of data collected on both circulating and dietary FA, and by the influence of FA metabolism [3, 4]. The strength of associations between dietary and circulating FA may also vary between participants with different demographic, lifestyle, and health characteristics. One study concluded that associations were relatively constant regardless of characteristics such as age, gender, body weight, smoking, alcohol drinking, and disease status [5]. However, other studies concluded that gender, country of birth, smoking and disease status modified the association between circulating and dietary intakes of EPA and DHA, but not LA [6, 7]. Circulating FA are typically expressed as relative proportions (\% of total FA). At present, it is unresolved whether levels of circulating FA should be expressed as relative proportions (\% of total FA) or as absolute concentrations $(\mu \mathrm{g} / \mathrm{mL})[8-$ $10]$.

In a cross-sectional analysis of data from 2 cohort studies, we investigated the influence of demographic, lifestyle, and health characteristics on the relation between self-reported dietary intake and circulating levels of LA, ALA, EPA, and DHA. We also explored differences between expressing levels of circulating FA as relative proportions and as absolute concentrations.

\section{Methods}

\section{Study Populations}

The current cross-sectional analysis is based on pooled data of participants from 2 Dutch cohorts; the Cohort study on Diabetes and Atherosclerosis Maastricht (CODAM study) and the Hoorn study. Details on the recruitment and selection of participants are given in online supplemental Data 1 (for all online suppl. material, see www.karger.com/doi/10.1159/000486244). The study protocols were approved by the local medical Ethics Committees, and all participants gave their written informed consent before entering the study. The same research protocols were used in both studies for assessing dietary intake and circulating FA. From the 1,398 participants in the pooled cohorts, we excluded 198 participants with missing data on circulating FA (17 from CODAM; 181 from Hoorn), 20 participants with missing dietary intake data, 8 with extreme energy intake $(<2,092 \mathrm{~kJ} /$ day [500 kcal] or $>14,644 \mathrm{~kJ} /$ day $[3,500 \mathrm{kcal}]$ in women, $<3,347 \mathrm{~kJ} /$ day $[800 \mathrm{kcal}]$ or $>16,736 \mathrm{~kJ} /$ day $[4,000 \mathrm{kcal}]$ in men), and one with implausible values in the FA profile (>100\%). In total, 1,171 participants were included (469 from CODAM, 702 from Hoorn).

\section{Dietary Intake Assessment}

In both cohorts, dietary intake over the past year was assessed using a self-administered 79-item semi-quantitative food frequency questionnaire [11]. Dietary intakes were calculated using an extended version of the Dutch Food Composition table from 2001 (NEVO) [12]. For total fat intake, the relative validity of the questionnaire in a Dutch population was between 0.69 and 0.74 for men and between 0.58 and 0.63 for women when comparing the food frequency questionnaire with 12 monthly $24 \mathrm{~h}$ recalls [13].

Potential energy under-reporters were identified on the basis of disparities between reported energy intakes and predicted energy requirements, using Goldberg's cutoff point for the ratio of energy intake to basal metabolic rate ratio (EI:BMR $<1.10)$, with physical activity level estimated to be $1.55[14,15]$.

\section{Circulating FA Assessment}

Venous blood samples were collected after overnight fast and stored at $-80{ }^{\circ} \mathrm{C}$ until use. FA composition in EDTA plasma (CODAM study) and serum (Hoorn study) was analyzed by gas liquid chromatography with flame ionization detection (AS Vitas, Oslo Innovation Center, Oslo, Norway) as described previously [16]. FA were expressed as relative proportions of the total area under the curve ( $\%$ of total FA) and as absolute concentrations ( $\mu \mathrm{g} /$ $\mathrm{mL})$. In the present analyses, we studied the FA that are synthesized endogenously in limited amounts or not synthesized at all, that is, LA, ALA, EPA, and DHA.

\section{Demographic, Lifestyle, and Health Characteristics}

Self-administered questionnaires were completed on demographics, lifestyle, and medication use. CVD was defined as selfreported history of myocardial infarction, stroke, bypass surgery of the coronary arteries, balloon dilatation or stent placement, or the presence of signs of myocardial infarction or ischemia on an electrocardiogram, or the presence of an ankle-arm index $<0.9$ in either leg. All participants underwent a standard $75 \mathrm{~g}$ oral glucose tolerance test, except those with previously diagnosed diabetes. Participants were classified as having normal glucose tolerance (NGT), impaired glucose metabolism, or type 2 diabetes mellitus 
(T2DM) according to the 1999 World Health Organization criteria [17]. Height $(\mathrm{m})$ and body weight $(\mathrm{kg})$ were measured with the participants wearing light clothing and no shoes. Waist circumference was measured with a tape midway between the lowest rib margin and the anterior superior spina iliaca.

\section{Statistical Analysis}

Participants' characteristics are presented as means \pm SD, median (interquartile range), or percentages, depending on the type and distribution of variables. Prior to further analysis, self-reported dietary and circulating proportions of ALA, EPA, and DHA were log-transformed toward a normal distribution of the residuals.

As a proxy for correlation coefficients, we calculated standardized linear regression coefficients (95\% CI) for the association of circulating FA (\% of total FA) as the dependent variable, with selfreported dietary FA (\% of total energy intake) as the independent variable, adjusted for original cohort. To assess the influence of demographic, lifestyle, and health characteristics on the standardized regression coefficients, dummy variables were created for the characteristics and interaction terms between dietary FA and the dummy variables were tested for significance in the regression models. To create dummy variables, the characteristics were categorized as follows: gender into men and women; age (y) and physical activity (min per week $\mathrm{x}$ intensity) into tertiles; smoking status into never, former, and current smokers; alcohol intake into no $(<0.1 \mathrm{~g} /$ day $)$, moderate $(<30.0 \mathrm{~g} /$ day for men or $<20.0 \mathrm{~g} /$ day for women), and high ( $\geq 30.0 \mathrm{~g} /$ day for men and $\geq 20.0 \mathrm{~g} /$ day for women); body mass index (BMI) into normal $\left(<25 \mathrm{~kg} / \mathrm{m}^{2}\right)$, overweight $\left(25-30 \mathrm{~kg} / \mathrm{m}^{2}\right)$, and obese $\left(>30 \mathrm{~kg} / \mathrm{m}^{2}\right)$; waist into normal $(<94 \mathrm{~cm}$ for men and $<80 \mathrm{~cm}$ for women) increased $(94-102 \mathrm{~cm}$ for men and $80-88 \mathrm{~cm}$ for women), and high ( $>102 \mathrm{~cm}$ for men and $>88$ $\mathrm{cm}$ for women); lipid-lowering medication and CVD into no and yes; glucose tolerance status into NGT, impaired glucose metabolism, or T2DM; and energy reporting as normal and under-reporters.

We subsequently explored the association of each participant characteristic on proportions of circulating LA, ALA, EPA, and DHA. The proportion of the total variation accounted for by each determinant was calculated by $\mathrm{R}^{2}$ change in multivariable linear regression analysis. This model also controlled for cohort, total energy intake $(\mathrm{kJ})$ and intakes from carbohydrate, protein, saturated, mono-unsaturated, and trans FA (\%En). Two-sided $p$ value $<0.05$ was considered to be statistically significant. To address the question on how to express and interpret levels of circulating FA, regression coefficients between circulating FA expressed as relative proportions and as absolute concentrations were calculated, and all analyses were repeated with circulating FA expressed as absolute concentrations $(\mu \mathrm{g} / \mathrm{mL})$. All analyses were performed using IBM SPSS Statistics 21 for Windows 7.

\section{Results}

The mean age of the population was $68 \pm 7$ years, $54 \%$ were men, and mean BMI was $28.0 \pm 4.2 \mathrm{~kg} / \mathrm{m}^{2}$. Of the participants, 32\% never smoked, 35\% had T2DM, 49\% had prevalent CVD or a history of CVD, and $47 \%$ used anti-hypertensive drugs (Table 1).
Table 1. Baseline characteristics of the study population

Total population

$(n=1,171)$

\begin{tabular}{|c|c|}
\hline Age, years & $67.9 \pm 7.1$ \\
\hline Gender, men, \% & 53.9 \\
\hline $\mathrm{BMI}, \mathrm{kg} / \mathrm{m}^{2}$ & $28.0 \pm 4.2$ \\
\hline \multicolumn{2}{|l|}{ Waist circumference, $\%$} \\
\hline Normal & 19.0 \\
\hline Increased & 26.0 \\
\hline High & 55.0 \\
\hline Physical activity, min/week*intensity & $6.2 \pm 4.7$ \\
\hline \multicolumn{2}{|l|}{ Smoking status, \% } \\
\hline Never & 31.5 \\
\hline Former & 51.1 \\
\hline Current & 16.7 \\
\hline Education level (low) ${ }^{\dagger}, \%$ & 50.5 \\
\hline Cardiovascular disease (yes), $\%$ & 49.9 \\
\hline \multicolumn{2}{|l|}{ Glucose tolerance status, $\%$} \\
\hline Normal glucose tolerance & 40.2 \\
\hline Impaired glucose metabolism & 24.9 \\
\hline T2DM & 34.9 \\
\hline \multicolumn{2}{|l|}{ Medication use (yes), \% } \\
\hline Anti-hypertensives & 46.9 \\
\hline Lipid lowering & 27.8 \\
\hline \multicolumn{2}{|l|}{ Dietary intake } \\
\hline Energy intake, MJ/day & $8.4 \pm 2.2$ \\
\hline EI:BMR & $1.35 \pm 0.34$ \\
\hline Total protein $(\% \mathrm{En})$ & $15.7 \pm 2.4$ \\
\hline Total carbohydrates (\%En) & $45.5 \pm 6.7$ \\
\hline Total fat (\%En) & $34.7 \pm 5.5$ \\
\hline SAFA (\%En) & $13.7 \pm 2.7$ \\
\hline MUFA (\%En) & $10.9 \pm 2.2$ \\
\hline PUFA (\%En) & $6.6 \pm 1.8$ \\
\hline TFA (\%En) & $1.1 \pm 0.3$ \\
\hline \multicolumn{2}{|l|}{ Alcohol intake } \\
\hline No & 15.9 \\
\hline Moderate & 67.4 \\
\hline High & 16.7 \\
\hline
\end{tabular}

${ }^{\text {a }}$ Values are presented as mean \pm SD or $n(\%)$.

$\dagger$ Only assessed in Hoorn cohort.

BMI, body mass index; T2DM, type 2 diabetes mellitus; \%En, percentage of energy; SAFA, saturated fatty acids; MUFA, monounsaturated fatty acids; PUFA, poly-unsaturated fatty acids; TFA, trans fatty acids; LA, linoleic acid; ALA, alpha-linoleic acid; EPA eicosapentaenoic acid; DHA, docosahexaenoic acid; EI:BMR, ratio of EI (energy intake) to BMR (basal metabolic rate). Waist circumference was categorized as normal $(<94 \mathrm{~cm}$ for men and $<80.0 \mathrm{~cm}$ for women), increased (94-102 $\mathrm{cm}$ for men and $80-88 \mathrm{~cm}$ for women), and high ( $>102 \mathrm{~cm}$ for men and $>88 \mathrm{~cm}$ for women). Alcohol intake was categorized as no $(<0.1 \mathrm{~g} /$ day $)$, moderate $(<30.0$ $\mathrm{g} /$ day for men or $<20.0 \mathrm{~g} /$ day for women), and high ( $\geq 30.0 \mathrm{~g} /$ day for men and $\geq 20.0 \mathrm{~g} /$ day for women). 


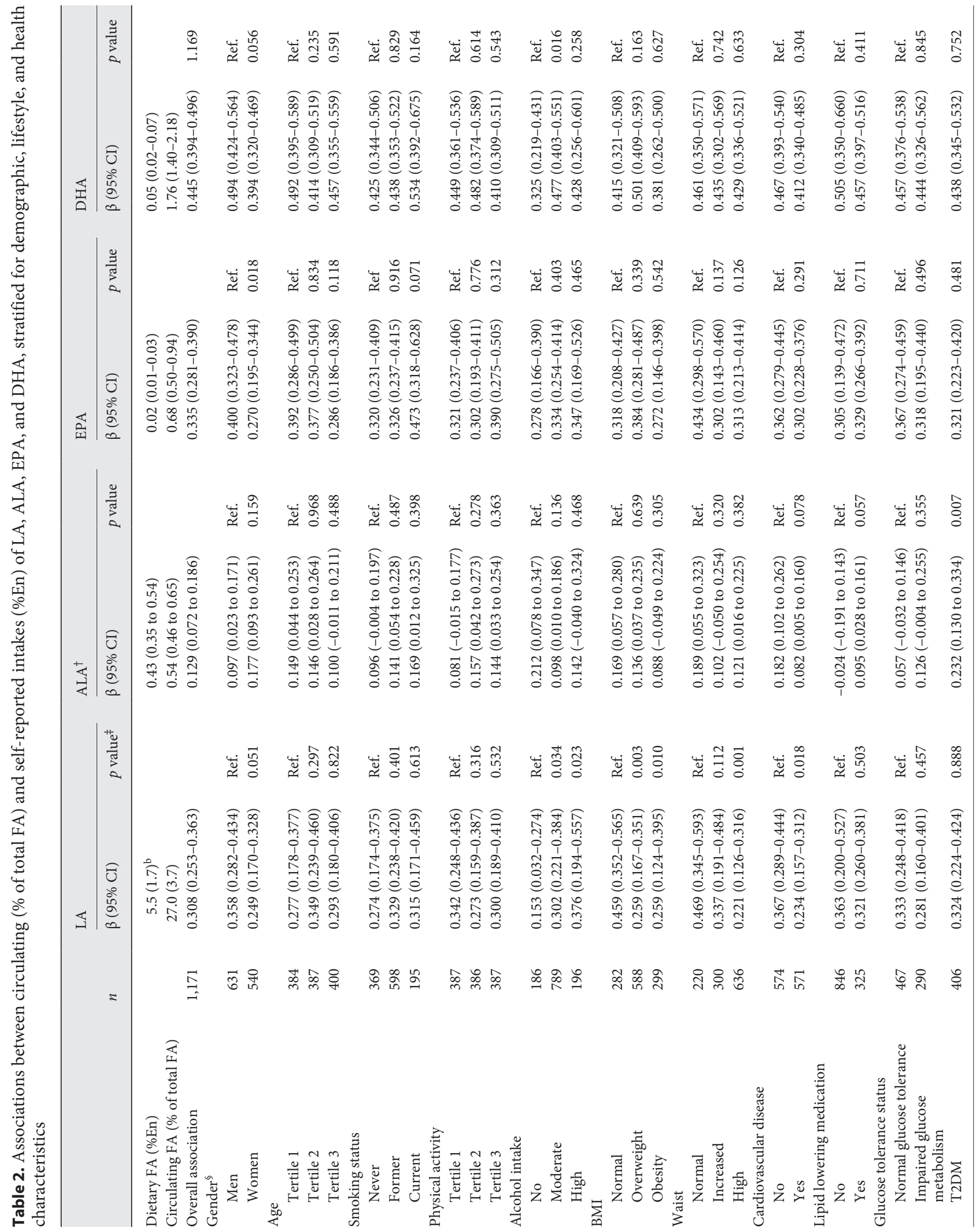




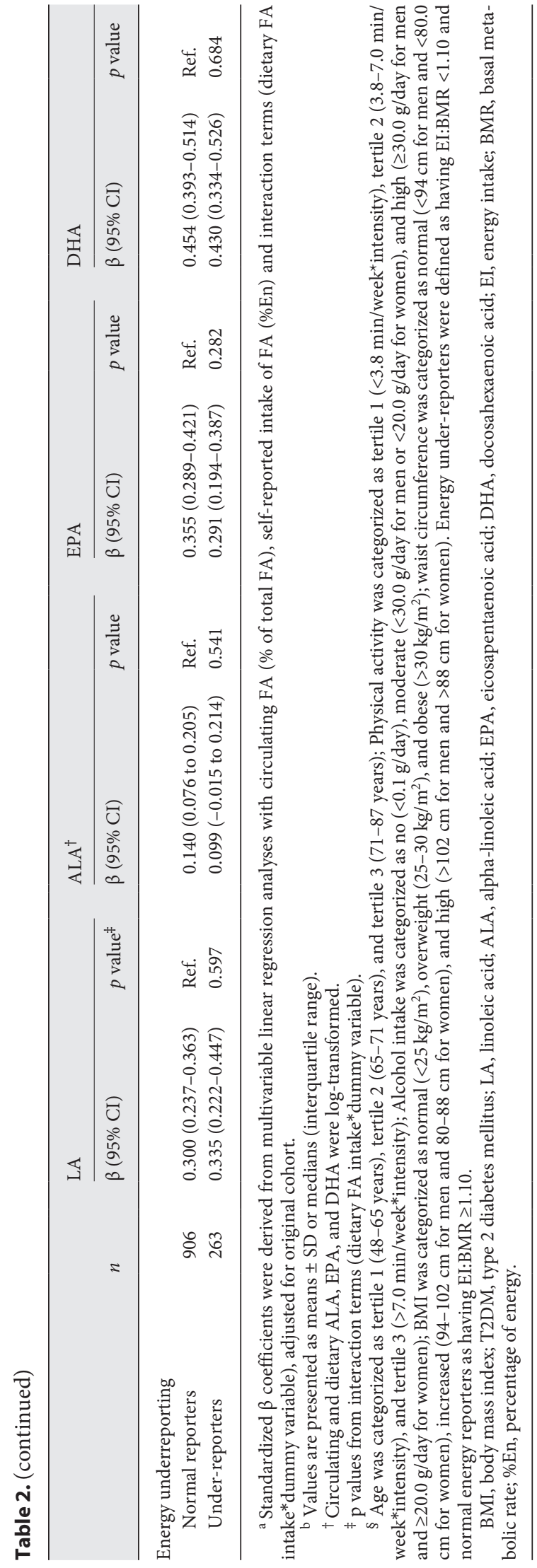

Biomarkers of Dietary Fat Intake
In the total population, standardized regression coefficients between dietary FA and relative proportions of circulating FA ( $\%$ of total FA) were as follows: LA $\beta=0.31$ (95\% CI 0.25-0.36), ALA $\beta=0.13$ (95\% CI 0.07-0.19), EPA $\beta=0.34$ (95\% CI 0.28-0.39), and DHA $\beta=0.45$ (95\% CI 0.39-0.50; Table 2).

Several participant characteristics modified the strength of the association between dietary and circulating ( $\%$ of total FA) LA. The association was stronger among participants with a normal BMI $(\beta=0.46 ; 95 \% \mathrm{CI}$ $0.35-0.57)$ compared to overweight $(\beta=0.26 ; 95 \%$ CI $\left.0.17-0.35, \mathrm{p}_{\text {int }}=0.003\right)$ or obese $(\beta=0.26$; $95 \%$ CI 0.12 $\left.0.40, \mathrm{p}_{\text {int }}=0.01\right)$ participants, among participants with a normal $(\beta=0.47 ; 95 \%$ CI $0.34-0.59)$ vs. a high waist circumference $\left(\beta=0.22 ; 95 \%\right.$ CI $0.13-0.32$, $\left.p_{\text {int }}=0.001\right)$, among participants without CVD $(\beta=0.37$; $95 \%$ CI 0.29 $0.44)$ vs. with CVD $\left(\beta=0.23\right.$; $95 \%$ CI $0.16-0.31$, $\mathrm{p}_{\text {int }}=$ $0.02)$, and among participants with a higher $(\beta=0.38$; 95\% CI 0.19-0.56, $\left.\mathrm{p}_{\text {int }}=0.02\right)$ and moderate $(\beta=0.30$; $95 \%$ CI 0.22-0.38, $\left.\mathrm{p}_{\text {int }}=0.03\right)$ alcohol intake vs no alcohol intake ( $\beta=0.15$; 95\% CI 0.03-0.27).

For ALA, EPA, and DHA, fewer participant characteristics were identified that modified the strength of the association between dietary and circulating (\% of total FA) FA. The association between dietary and circulating ALA was stronger among participants with T2DM $(\beta=0.23$; 95\% CI $0.13-0.33)$ than among participants with NGT $\left(\beta=0.06 ; 95 \%\right.$ CI -0.03 to $\left.0.25, p_{\text {int }}=0.01\right)$. The association between dietary and circulating EPA was stronger among men $(\beta=0.40 ; 95 \%$ CI $0.32-0.48)$ than women ( $\beta=0.27 ; 95 \%$ CI $\left.0.19-0.35, \mathrm{p}_{\text {int }}=0.02\right)$, and the association between dietary and circulating DHA was stronger among participants with a moderate $\left(\beta=0.48 ; 95 \%\right.$ CI $\left.0.40-0.55, p_{\text {int }}=0.02\right)$ vs. no alcohol intake ( $\beta=0.33$; 95\% CI 0.22-0.43). Adjustment for additional demographic, lifestyle, health and dietary variables resulted in similar differences, except that the modifying effects of gender were more overt and statistically significant for ALA, EPA, and DHA (online suppl. Table 1).

To explore the nature of the differences in associations between participant characteristics, determinants of proportions of circulating LA, ALA, EPA, and DHA (\% of total FA) were assessed by multivariable regression analyses. All demographic, lifestyle, health, and dietary variables together explained $25,12,18$, and $27 \%$ of variation (total $\mathrm{R}^{2}$ ) in circulating LA, ALA, EPA, and DHA, respectively (Table 3). Self-reported intakes of LA, ALA, EPA, and DHA explained the largest part of the variations: 7, 2, 8, and $16 \%$ (partial $\mathrm{R}^{2}$ ), respectively. 
Table 3. Demographic, lifestyle and health determinants of circulating LA, ALA, EPA, and DHA (\% of total FA) ${ }^{\mathrm{a}}$

\begin{tabular}{|c|c|c|c|c|c|c|c|c|c|c|c|c|}
\hline & \multicolumn{3}{|l|}{ LA } & \multicolumn{3}{|l|}{$\mathrm{ALA}^{\dagger}$} & \multicolumn{3}{|l|}{ EPA } & \multicolumn{3}{|l|}{ DHA } \\
\hline & $\beta$ & $p$ value & $\begin{array}{l}\text { partial } \\
\mathrm{R}^{2}, \%\end{array}$ & $\beta$ & $p$ value & $\begin{array}{l}\text { partial } \\
\mathrm{R}^{2}, \%\end{array}$ & $\beta$ & $p$ value & $\begin{array}{l}\text { partial } \\
\mathrm{R}^{2}, \%\end{array}$ & $\beta$ & $p$ value & $\begin{array}{l}\text { partial } \\
\mathrm{R}^{2}, \%\end{array}$ \\
\hline Age, years ${ }^{\ddagger}$ & 0.062 & 0.064 & 0.2 & -0.044 & 0.223 & 0.1 & 0.109 & 0.002 & 0.7 & 0.183 & $<0.001$ & 2.1 \\
\hline Gender $($ ref. $=$ men $)$ & -0.042 & 0.424 & 0.0 & -0.156 & 0.006 & 0.6 & 0.054 & 0.323 & 0.1 & 0.009 & 0.856 & 0.0 \\
\hline $\begin{array}{l}\text { Physical activity, } \min / \text { week }^{*} \text { intensity } \\
\text { Smoking status (ref. = never) }\end{array}$ & \multicolumn{12}{|c|}{ Smoking status (ref. $=$ never) } \\
\hline Former & -0.020 & 0.531 & 0.0 & -0.103 & 0.003 & 0.7 & -0.019 & 0.584 & 0.1 & -0.023 & 0.478 & 0.1 \\
\hline Current & -0.014 & 0.655 & & -0.068 & 0.044 & & 0.010 & 0.753 & & 0.014 & 0.660 & \\
\hline \multicolumn{13}{|l|}{ Alcohol intake (ref. $=$ no) } \\
\hline Moderate & 0.003 & 0.943 & 0.1 & -0.037 & 0.371 & 0.1 & 0.087 & 0.029 & 1.1 & 0.097 & 0.010 & 0.5 \\
\hline High & -0.052 & 0.356 & & -0.064 & 0.261 & & 0.211 & $<0.001$ & & 0.132 & 0.010 & \\
\hline BMI, $\mathrm{kg} / \mathrm{m}^{2}$ & -0.055 & 0.215 & 0.1 & 0.027 & 0.576 & 0.0 & 0.013 & 0.789 & 0.0 & -0.039 & 0.372 & 0.1 \\
\hline \multicolumn{13}{|l|}{ Waist circumference (ref. $=$ normal) } \\
\hline Increased & -0.120 & 0.001 & 1.4 & 0.078 & 0.050 & 0.3 & 0.012 & 0.760 & 0.3 & 0.008 & 0.832 & 0.1 \\
\hline High & -0.216 & $<0.001$ & & 0.083 & 0.114 & & 0.081 & 0.112 & & 0.056 & 0.242 & \\
\hline \multicolumn{13}{|l|}{ Glucose tolerance status (ref. $=$ normal) } \\
\hline Impaired glucose metabolism & -0.082 & 0.006 & 1.2 & 0.020 & 0.540 & 0.1 & 0.009 & 0.768 & 1.6 & 0.020 & 0.496 & 0.2 \\
\hline $\mathrm{T} 2 \mathrm{DM}$ & -0.126 & $<0.001$ & & -0.013 & 0.715 & & -0.134 & $<0.001$ & & -0.038 & 0.235 & \\
\hline Anti-hypertensive medication $($ ref. $=$ no $)$ & -0.005 & 0.874 & 0.0 & -0.025 & 0.463 & 0.0 & -0.040 & 0.215 & 0.1 & -0.066 & 0.032 & 0.3 \\
\hline Lipid lowering medication $($ ref. $=$ no $)$ & -0.160 & $<0.001$ & 1.9 & -0.017 & 0.607 & 0.0 & 0.050 & 0.125 & 0.2 & 0.091 & 0.003 & 0.6 \\
\hline Cardiovascular disease $($ ref. $=$ no $)$ & -0.070 & 0.016 & 0.4 & 0.046 & 0.140 & 0.2 & -0.007 & 0.828 & 0.0 & -0.016 & 0.583 & 0.0 \\
\hline EI:BMR & -0.042 & 0.704 & 0.0 & 0.194 & 0.103 & 0.2 & 0.102 & 0.377 & 0.1 & -0.013 & 0.904 & 0.0 \\
\hline \multicolumn{13}{|l|}{ Fatty acid intake (\%En) } \\
\hline LA & 0.334 & $<0.001$ & 6.8 & & & & & & & & & \\
\hline $\mathrm{ALA}^{\dagger}$ & & & & 0.161 & $<0.001$ & 2.0 & & & & & & \\
\hline EPA & & & & & & & 0.313 & $<0.001$ & 8.4 & & & \\
\hline DHA & & & & & & & & & & 0.433 & $<0.001$ & 16.0 \\
\hline Model $\mathrm{R}^{2}$ & & & 24.9 & & & 11.5 & & & 17.6 & & & 26.8 \\
\hline $\begin{array}{l}\text { a (Partial) } \mathrm{R}^{2} \text { derived from multivaria } \\
\text { activity score, smoking status, cardiovascu } \\
\text { specific self-reported FA intake, additiona } \\
{ }^{\dagger} \text { Circulating and dietary ALA, EPA an } \\
{ }^{\ddagger} \text { Alcohol intake was categorized as no } \\
\text { day for women); waist circumference was } \\
\text { women), and high ( }>102 \mathrm{~cm} \text { for men and } \\
\text { LA, linoleic acid; ALA, alpha-linoleic a } \\
\text { sal metabolic rate. }\end{array}$ & $\begin{array}{l}\text { le model } \\
\text { ar diseas } \\
\text { lly contro } \\
\text { d DHA v } \\
(<0.1 \mathrm{~g} / \mathrm{d} \\
\text { categoriz } \\
88 \mathrm{~cm} \mathrm{fo} \\
\text { cid; EPA }\end{array}$ & $\begin{array}{l}\text { for circu } \\
\text { glucose t } \\
\text { led for to } \\
\text { ere log-tr } \\
\text { y), mode } \\
\text { d as norn } \\
\text { women. } \\
\text { icosapen }\end{array}$ & $\begin{array}{l}\text { ting FA } \\
\text { lerance s } \\
\text { l energy } \\
\text { nsformec } \\
\text { te }(<30.0 \\
l(<94 \mathrm{cr} \\
\text { enoic aci }\end{array}$ & $\begin{array}{l}\text { of total } \\
\text { tus, anti- } \\
\text { take and } \\
\text { for men for } \\
\text { DHA, d }\end{array}$ & $\begin{array}{l}\text { intakes fr } \\
\text { men or }< \\
\text { and }<80 \text {. } \\
\text { ocosahex }\end{array}$ & $\begin{array}{l}\text { ding ori } \\
\text { sive and } 1 \\
\text { om carb } \\
20.0 \mathrm{~g} / \mathrm{da} \\
\mathrm{cm} \text { for } \\
\text { enoic ac }\end{array}$ & $\begin{array}{l}\text { ial coho } \\
\text { d loweri } \\
\text { ydrate, } p \\
\text { or wome } \\
\text { men), in } \\
\text { EI, ener }\end{array}$ & $\begin{array}{l}\text { rt, age, se } \\
\text { ng medic } \\
\text { rotein, SI } \\
\text { ), and h } \\
\text { creased ( } \\
\text { gy intake }\end{array}$ & $\begin{array}{l}\mathrm{x}, \mathrm{BMI}, \\
\text { ation, EI } \\
\text { A, MUF } \\
\text { igh }(\geq 30 \\
94-102 \mathrm{c} \\
\% \mathrm{En}, \mathrm{pe}\end{array}$ & $\begin{array}{l}\text { arst circu } \\
\text { and } \mathrm{TF} \\
\mathrm{g} / \mathrm{day} \text { fo } \\
\text { for mer }\end{array}$ & $\begin{array}{l}\text { mference } \\
\text { hol intak } \\
\text { men an } \\
\text { and } 80- \\
\text { f energy; }\end{array}$ & $\begin{array}{l}\text { physica } \\
\text {, and the } \\
1 \geq 20.0 \mathrm{~g} / \\
38 \mathrm{~cm} \text { for } \\
\mathrm{BMR}, \mathrm{ba}\end{array}$ \\
\hline
\end{tabular}

Standardized regression coefficients between relative proportions (\% of total FA) and absolute concentrations $(\mu \mathrm{g} / \mathrm{mL})$ of circulating FA were as follows: LA $\beta=0.39$ (95\% CI 0.34-0.44), ALA $\beta=0.84$ (95\% CI 0.81-0.86), EPA $\beta=0.93$ (95\% CI 0.90-0.95), and DHA $\beta=0.83(95 \%$ CI $0.80-0.87)$. Standardized regression coefficients between dietary FA and absolute concentrations of circulating FA $(\mu \mathrm{g} / \mathrm{mL})$ were as follows: LA $\beta=0.19(95 \%$ CI $0.13-0.24$ ), ALA $\beta=0.10$ (95\% CI 0.04-0.16), EPA $\beta=$ 0.31 (95\% CI 0.25-0.36), and DHA $\beta=0.41$ (95\% CI $0.36-$ 0.46). Expressing circulating FA as absolute concentrations $(\mu \mathrm{g} / \mathrm{mL})$ attenuated all modifying effects from participant characteristics on the associations with FA intake, except for the modifying effects of gender on EPA and DHA, and alcohol on DHA (online suppl. Table 2). For circulating FA expressed as absolute concentrations $(\mu \mathrm{g} / \mathrm{mL})$, all variables together explained $13,7,19$, and $25 \%$ of variation (total $\mathrm{R}^{2}$ ) in circulating LA, ALA, EPA, and DHA, respectively, and intake of LA, ALA, EPA, and DHA explained 2, 1, 6, and $12 \%$ (partial $\mathrm{R}^{2}$ ), respectively (online suppl. Table 3 ).

\section{Discussion}

Participant characteristics, such as BMI and alcohol intake, as well as the way of expressing circulating FA, as proportions or concentrations, influenced associa- 
tions between self-reported dietary and circulating FA, in particular for LA. For each of the examined FA, its dietary intake was the primary, but not the only determinant of circulating FA. Other demographic, lifestyle, and health characteristics also influenced levels of circulating FA.

In agreement with earlier studies [4], the associations between dietary intakes and proportions of circulating LA, EPA and DHA were relatively strong $(\beta=0.31, \beta=$ 0.34 , and $\beta=0.45$, respectively) but weaker for ALA ( $\beta=$ 0.13). Although ALA is not synthesized endogenously, this weaker association may be explained by the rapid oxidation of dietary ALA in the body $[18,19]$ and by the lower precision of measuring ALA intake from the diet [20].

In general, associations between dietary and circulating FA may be attenuated by measurement errors and by FA metabolism [3, 4]. Earlier research shows that participants of older age, with higher BMI, lower level of education, and higher health consciousness, and women tend to under-report energy intake [21-23], which may affect the reliability of estimated self-reported FA intakes. On the other hand, factors such as smoking and age have been shown to affect proportions of circulating FA [24, 25], and some studies showed that women have more endogenous synthesis of EPA and DHA than men $[26,27]$. These factors may cause weaker associations in some subgroups, or attenuate overall associations between reported dietary and circulating FA.

We observed that several participant characteristics substantially influenced the associations between reported dietary intakes and circulating proportions of FA. For example, in normal weight participants, the association between dietary and circulating proportions of LA was $\beta=0.46$, which is generally considered 'moderate' for a biomarker of dietary intake, whereas the correlation was $\beta=0.26$ in obese participants. These observed differences could be due to errors in the data on dietary or circulating FA, or due to biological differences in FA metabolism between non-obese and obese participants.

To explore the nature of the observed differences, we assessed the association of a range of participant characteristics with proportions of circulating FA. We did not find weaker associations in people who underreport total energy intake, although this has been suggested to be more prominent in obese people [28, 29]. Hence, energy underreporting is unlikely to fully explain the weaker associations in obese participants. For circulating LA, we observed that independent of self-reported LA intake, a high BMI, a high waist circumference, and an unfavor-

Biomarkers of Dietary Fat Intake able health status were inversely associated with the proportion of LA in blood. Thus, participant characteristics may have an impact on FA metabolism and should be further explored. It is possible that delta 6-desaturase activity, the enzyme converting LA into gamma-linoleic acid, is altered in participants with insulin resistance, although at present there are no studies supporting this finding $[30,31]$. Another explanation may be that in the presence of non-alcoholic fatty liver disease, hypertriglyceridemia, and insulin resistance, de novo lipogenesis is upregulated or FA oxidation is downregulated, promoting a higher proportion of SFA and MUFA in blood, and consequently a lower proportion of circulating LA [4, 32].

We also observed that older age was associated with higher proportions of circulating EPA and DHA, in line with earlier studies $[24,33]$. Our observation that women had lower circulating proportions of ALA than men would be in agreement with studies showing that women have a larger capacity to convert ALA into EPA and DHA under the influence of sex hormones [26]. However, most women in our cohort were postmenopausal and the proportion of EPA and DHA did not differ between men and women. Thus, there must be other factors and unmeasured differences between men and women affecting the proportion of circulating poly-unsaturated FA. Overall, our data confirm earlier findings that participant characteristics and lifestyle factors other than diet may influence circulating proportions of FA $[3,4]$. These factors should be taken into account when applying circulating FA as biomarkers of FA intake.

We also explored differences between expressing circulating FA as relative proportions or as absolute concentrations when using these as biomarkers of intake. We confirmed earlier findings that circulating FA as absolute concentrations $(\mu \mathrm{g} / \mathrm{mL})$ resulted in weaker associations with dietary intake than as proportions (\% of total FA), in particular for LA $[8,9]$. On the other hand, associations between self-reported LA and circulating LA expressed as absolute concentrations were less affected by alcohol intake, BMI, and waist circumference. This suggests that either our study had insufficient power to identify significant modifications when circulating LA was expressed as absolute concentration, or that associations between self-reported and circulating FA as absolute concentrations may be less dependent on participant characteristics. Thus, whether circulating FA can better be expressed as absolute concentrations or as relative proportions may depend on the research question. 
Several limitations of our study should be mentioned. First, the observational nature of our study leaves room for reverse causation and residual confounding. For example, potential sources of residual confounding are socioeconomical status [34], which was not measured in one of our cohorts, and the background diet. The background diet may affect levels of specific circulating FA in 2 ways. It may be direct, for example, the uptake of omega-3 FA may be improved when consumed with a high fat meal [35]. It may also be indirect, for example, when other FA from the diet are elongated and desaturated and/or when FA are endogenously synthesized from carbohydrates and mixed into the circulating FA pool [36]. However, our additional analyses (online suppl. Table 1), including adjustments for background diet, did not result in different observations. The influence of these participant characteristics on the relation between dietary and circulating FA should be further studied in settings where dietary intakes are controlled. Second, we determined total FA in plasma (CODAM study) and serum (Hoorn study) instead of measuring separate blood lipid sub-fractions such as triglycerides, cholesteryl esters, phospholipids, or non-esterified FA. Proportions of FA differ between sub-fractions, and a change in the pool size of one sub-fraction, for example due to a disease, may potentially affect the total plasma or serum FA composition and thus complicate the interpretation of our results [4]. Also, each sub-fraction may reflect FA intake over different time frames before blood sampling and result in different associations with self-reported intakes. Thus, it might be of interest to also further study the influence of demographic, lifestyle, and health characteristics on the associations in different blood lipid sub-fractions and in adipose tissue. Third, information on intake of flaxseed or fish oil supplements was not collected. Food consumption data from the Netherlands show that in $2007-20100 \%$ of ALA and LA and $6 \%$ of total EPA and DHA intake originated from dietary supplements [37]. Consequently, in our study, the intake of EPA and DHA may have been slightly underestimated, which may have contributed to lower correlations between intake and blood markers.

In conclusion, our analysis suggests that demographic, lifestyle, health characteristics, and the way of expressing levels of circulating FA influence the strength of the associations between dietary and circulating FA. Better understanding of the factors that determine levels of circulating FA will help to improve their application as biomarkers of FA intake.

\section{Ethics Statement}

The study protocols of both cohorts were approved by the local medical Ethics Committees, and all participants gave their written informed consent before entering the study.

\section{Disclosure Statement}

A.J.W., M.A., and P.L.Z. are employed by Unilever R\&D Vlaardingen, the Netherlands; S.E.M.D.H. was an MSc student at Unilever R\&D and Wageningen University at the time of conducting the study. Unilever markets food products made of vegetable oils, including margarines and dressings. C.A.D. is a co-founder, stock-owner, board-member and consultant for the contract laboratory Vitas Ltd., in the Oslo Innovation Park, Oslo, Norway. Other authors declared no conflicts of interest to disclose.

\section{Funding Sources}

Research Council of Norway funded the fatty acid measurements. The Hoorn Study was supported by grants from the Netherlands Organization for Scientific Research (NWO), the Dutch Diabetes Research Foundation, the Netherlands Heart Foundation, and Novartis Pharma BV, the Netherlands. The CODAM study was supported by a grant from the Netherlands Organization for Scientific Research (NWO) and the Dutch Diabetes Research Foundation. The funding sources did not play a role in any part of the study.

\section{Author Contributions}

The authors' contributions were as follows: C.J.K., C.G.S., C.D.A.S., J.M.D., and M.M.J.G. were the principal investigators of the Hoorn and CODAM study, and H.R., C.A.D., and A.E. enabled the fatty acid measurements. A.J.W., S.E.M.D.H., M.A., E.J.M.F., G.J.W., P.L.Z., J.M.D., and M.M.J.G. designed the present study and A.J.W., S.E.M.D.H., P.L.Z., J.M.D., and M.M.J.G. analyzed and interpreted the data, and A.J.W. wrote the manuscript. All authors reviewed the manuscript and provided comments. All authors approved of the final manuscript.

References

Ann Nutr Metab 2018;72:117-125 DOI: $10.1159 / 000486244$
1 Hedrick VE, Dietrich AM, Estabrooks PA, Savla J, Serrano E, Davy BM: Dietary biomarkers: advances, limitations and future directions. Nutr J 2012;11:109.

2 Willett WC: Nutritional Epidemiology, ed 2. New York, Oxford University Press, 1998.

3 Arab L: Biomarkers of fat and fatty acid intake. J Nutr 2003;133(suppl 3):925S-932S.

4 Hodson L, Skeaff CM, Fielding BA: Fatty acid composition of adipose tissue and blood in humans and its use as a biomarker of dietary intake. Prog Lipid Res 2008;47:348380.

Wanders et al. 
5 Ma J, Folsom AR, Shahar E, Eckfeldt JH: Plasma fatty acid composition as an indicator of habitual dietary fat intake in middle-aged adults. The Atherosclerosis Risk in Communities (ARIC) Study Investigators. Am J Clin Nutr 1995;62:564-571.

6 Hodge AM, Simpson JA, Gibson RA, Sinclair AJ, Makrides M, O'Dea K, English DR, Giles GG: Plasma phospholipid fatty acid composition as a biomarker of habitual dietary fat intake in an ethnically diverse cohort. Nutr Metab Cardiovasc Dis 2007;17:415-426.

7 Wallin A, Di Giuseppe D, Burgaz A, Håkansson N, Cederholm T, Michaëlsson K, Wolk A: Validity of food frequency questionnairebased estimates of long-term long-chain n-3 polyunsaturated fatty acid intake. Eur J Nutr 2014;53:549-555.

8 Wanders AJ, Alssema M, van Greevenbroek MJ, Elshorbagy A, Zock PL, Dekker JM, Brouwer IA: Comment on Sergeant, et al: Impact of methods used to express levels of circulating fatty acids on the degree and direction of associations with blood lipids in humans. $\mathrm{Br}$ J Nutr 2016;115:2077-2078.

9 Bradbury KE, Skeaff CM, Crowe FL, Green TJ, Hodson L: Serum fatty acid reference ranges: percentiles from a New Zealand national nutrition survey. Nutrients 2011;3: 152-163.

10 Sergeant S, Ruczinski I, Ivester P, Lee TC, Morgan TM, Nicklas BJ, Mathias RA, Chilton FH: Impact of methods used to express levels of circulating fatty acids on the degree and direction of associations with blood lipids in humans. Br J Nutr 2016;115:251-261.

11 Ocke MC, Bueno-de-Mesquita HB, Goddijn HE, Jansen A, Pols MA, van Staveren WA, Kromhout D: The Dutch EPIC food frequency questionnaire. I. Description of the questionnaire, and relative validity and reproducibility for food groups. Int J Epidemiol 1997; 26(suppl 1):S37-S48.

12 Voedingscentrum, Dutch Food Composition Database: NEVO. Bilthoven, The Netherlands, 2001.

13 Ocke MC, Bueno-de-Mesquita HB, Pols MA, Smit HA, van Staveren WA, Kromhout D: The Dutch EPIC food frequency questionnaire. II. Relative validity and reproducibility for nutrients. Int J Epidemiol 1997;26(suppl 1):S49-S58

14 Black AE: Critical evaluation of energy intake using the Goldberg cut-off for energy intake:basal metabolic rate. A practical guide to its calculation, use and limitations. Int J Obesity 2000;24:1119-1130.

15 Goldberg GR, Black AE, Jebb SA, Cole TJ, Murgatroyd PR, Coward WA, Prentice AM: Critical evaluation of energy intake data using fundamental principles of energy physiology: 1. Derivation of cut-offlimits to identify underrecording. Eur J Clin Nutr 1991;45:569-581.
16 Vinknes KJ, Elshorbagy AK, Nurk E, Drevon CA, Gjesdal CG, Tell GS, Nygård O, Vollset SE, Refsum H: Plasma stearoyl-CoA desaturase indices: association with lifestyle, diet, and body composition. Obesity 2013; 21:E294-E302.

17 World Health Organization, Definition, Diagnosis and Classification of Diabetes Mellitus and Its Complications. Report of a WHO Consultation. Geneva, 1999.

18 Arterburn LM, Hall EB, Oken H: Distribution, interconversion, and dose response of n-3 fatty acids in humans. Am J Clin Nutr 2006;83:1467S-1476S.

19 Goyens PL, Spilker ME, Zock PL, Katan MB, Mensink RP: Conversion of alpha-linolenic acid in humans is influenced by the absolute amounts of alpha-linolenic acid and linoleic acid in the diet and not by their ratio. Am J Clin Nutr 2006;84:44-53.

20 Pan A, Chen M, Chowdhury R, Wu JH, Sun Q, Campos H, Mozaffarian D, Hu FB: a-Linolenic acid and risk of cardiovascular disease: a systematic review and meta-analysis. Am J Clin Nutr 2012;96:1262-1273.

21 Livingstone MB, Black AE: Markers of the validity of reported energy intake. J Nutr 2003; 133(suppl 3):895S-920S.

22 Poslusna K, Ruprich J, de Vries JH, Jakubikova $M$, van't Veer P: Misreporting of energy and micronutrient intake estimated by food records and 24 hour recalls, control and adjustment methods in practice. Br J Nutr 2009; 101(suppl 2):S73-S85.

23 Lutomski JE, van den Broeck J, Harrington J, Shiely F, Perry IJ: Sociodemographic, lifestyle, mental health and dietary factors associated with direction of misreporting of energy intake. Public Health Nutr 2011;14:532541.

24 de Groot RH, van Boxtel MP, Schiepers OJ, Hornstra G, Jolles J: Age dependence of plasma phospholipid fatty acid levels: potential role of linoleic acid in the age-associated increase in docosahexaenoic acid and eicosapentaenoic acid concentrations. Br J Nutr 2009;102:1058-1064

25 Simon JA, Fong J, Bernert JT Jr, Browner WS: Relation of smoking and alcohol consumption to serum fatty acids. Am J Epidemiol 1996;144:325-334.

26 Burdge GC, Calder PC: Conversion of alphalinolenic acid to longer-chain polyunsaturated fatty acids in human adults. Reprod Nutr Dev 2005;45:581-597.

27 Giltay EJ, Gooren LJ, Toorians AW, Katan MB, Zock PL: Docosahexaenoic acid concentrations are higher in women than in men because of estrogenic effects. Am J Clin Nutr 2004;80:1167-1174.

28 Goris AH, Westerterp-Plantenga MS, Westerterp KR: Undereating and underrecording of habitual food intake in obese men: selective underreporting of fat intake. Am J Clin Nutr 2000;71:130-134.

29 Johansson L, Solvoll K, Bjørneboe GE, Drevon CA: Under- and overreporting of energy intake related to weight status and lifestyle in a nationwide sample. Am J Clin Nutr 1998;68: 266-274.

30 Montanaro MA, Rimoldi OJ, Igal RA, Montenegro S, Tarrés MC, Martínez SM, Brenner RR: Hepatic delta9, delta6, and delta5 desaturations in non-insulin-dependent diabetes mellitus eSS rats. Lipids 2003;38:827-832.

31 Forouhi NG, Imamura F, Sharp SJ, Koulman A, Schulze MB, Zheng J, Ye Z, Sluijs I, Guevara M, Huerta JM, Kröger J, Wang LY, Summerhill K, Griffin JL, Feskens EJ, Affret A, Amiano P, Boeing H, Dow C, Fagherazzi G, Franks PW, Gonzalez C, Kaaks R, Key TJ, Khaw KT, Kühn T, Mortensen LM, Nilsson PM, Overvad K, Pala V, Palli D, Panico S, Quirós JR, Rodriguez-Barranco M, Rolandsson O, Sacerdote C, Scalbert A, Slimani N, Spijkerman AM, Tjonneland A, Tormo MJ, Tumino R, van der A DL, van der Schouw YT, Langenberg C, Riboli E, Wareham NJ: Association of plasma phospholipid n-3 and n- 6 polyunsaturated fatty acids with type 2 diabetes: the EPIC-interAct case-cohort study. PLoS Med 2016;13:e1002094.

32 Donnelly KL, CI Smith CI, Schwarzenberg SJ, Jessurun J, Boldt MD, Parks EJ: Sources of fatty acids stored in liver and secreted via lipoproteins in patients with nonalcoholic fatty liver disease. J Clin Invest 2005;115:13431351.

33 Bolton-Smith C, Woodward M, Tavendale R: Evidence for age-related differences in the fatty acid composition of human adipose tissue, independent of diet. Eur J Clin Nutr 1997;51: 619-624.

34 Harris WS, Pottala JV, Lacey SM, Vasan RS, Larson MG, Robins SJ: Clinical correlates and heritability of erythrocyte eicosapentaenoic and docosahexaenoic acid content in the Framingham Heart Study. Atherosclerosis 2012;225:425-431.

35 Lawson LD, Hughes BG: Absorption of eicosapentaenoic acid and docosahexaenoic acid from fish oil triacylglycerols or fish oil ethyl esters co-ingested with a high-fat meal. Biochem Biophys Res Commun 1988;156:960963

36 Zock PL, Mensink RP, Harryvan J, de Vries JH, Katan MB: Fatty acids in serum cholesteryl esters as quantitative biomarkers of dietary intake in humans. Am J Epidemiol 1997; 145:1114-1122.

37 Van Rossum CTM, Fransen H, VerkaikKloosterman J, Buurma-Rethans EJM, Ocke MC: Dutch National Food Consumption Survey 2007-2010: Supporting Tables. Bilthoven, National Institute for Public Health and the Environment, 2011. 